\title{
Research on the Cultivation Model of Innovation and Entrepreneurship Talents Based on Three Creative Education
}

\author{
Shigang Wang \\ School of Electrical and Information Engineering \\ Guangxi University of Science and Technology \\ Liuzhou, China \\ 1784047367@qq.com
}

\author{
Shenghui Pan \\ School of Electrical and Information Engineering \\ Guangxi University of Science and Technology \\ Liuzhou, China
}

\author{
Zhenglin Li \\ School of Electrical and Information Engineering \\ Guangxi University of Science and Technology \\ Liuzhou, China
}

\begin{abstract}
According to the needs of the times, there is an urgent need for college students to carry out innovative education. Therefore, it is necessary to carry out the training mode of innovative and entrepreneurship talents based on three creative education. First of all, according to the training goal of "three innovation education", the author systematically decomposes and implements the knowledge structure, skill system and accomplishment requirements of talent training, and constructs a three training mode for college students to adapt to the characteristics of local colleges and universities. Secondly, the "three creative education" should be effectively incorporated into the teaching plan and credit system of professional education and cultural quality education, and a multi-level and threedimensional three creative education curriculum system should be established. Third, improve the rules and regulations, security system and incentive mechanism, and build a three platform for education and practice. Through the system of teaching theory and practice integration, effective combination of internal and external practice platform, innovation and entrepreneurship education to carry out the whole program, three-dimensional, systematic, personalized, cultivating high-quality innovative active spirit of innovation and strong independent entrepreneurship entrepreneurial talent.
\end{abstract}

Keywords-three creative education; innovation and entrepreneurship; models for talents cultivation; curriculum system

\section{INTRODUCTION}

The twenty-first century is full of innovation, creativity and entrepreneurship of the times, reform and opening up more than 30 years, China's economic and social development has made great progress, at the same time, China's higher education has also been rapid development [1]. With the expansion of colleges and universities and the "popularization" of higher education, the proportion of people receiving higher education has been greatly improved, and the corresponding employment results and employment methods have also undergone tremendous changes, by the gap between reality and employment expectations And the impact of traditional employment concepts, many college students began to feel at a loss for their own future. How to make college students get rid of employment difficulties, fundamentally help college students to establish the correct concept of employment and career choice, so that students in the correct career aspirations and beliefs to create a new self-display space, to achieve the value of life? Based on this social background, innovation and entrepreneurship education came into being [2-4]. UNESCO held an International Symposium on Education in the 21st Century in Beijing in November 1989 The conference held that entrepreneurship education was equally important as academic and vocational education and called entrepreneurship education "third this education passport ".

As early as 1990, China has carried out the basic education stage of the implementation of employment and entrepreneurship education project research, but the proportion of college students in China is relatively low [5]. According to the survey, in the entrepreneurial groups in China, "the entrepreneur with a college degree in all entrepreneurship group only $3.7 \%$ ", while the developed countries generally accounted for $20 \%-30 \%$. This shows that China's innovation and entrepreneurship education there is a big gap, its systematic, scientific and operability is not perfect [6]. In recent years, under the innovation and entrepreneurship education of college students in our country has achieved some results, but there are still many problems on the whole, such as the imperfect school teachers 'innovation and entrepreneurship education; the theoretical system of college students' innovation and entrepreneurship education is not perfect; The cultural atmosphere of education is not strong; college students to start a wide range of innovative entrepreneurship education and so on [7]. 
With the development of market economy system, more and more attention has been paid to the great role of innovation and entrepreneurship in economic development [8]. At the same time, the development of social economy has put forward higher requirements for the quality of talents [9]. From the current situation of economic development and educational reform and development, it is urgent for students to carry out innovation and entrepreneurship education, which is the requirement of the times and the inevitable trend of social development [10]. At present, all colleges and universities to carry out entrepreneurship education more and more attention, support those mastering knowledge innovation of college students entrepreneurship, become the main force in the field of national basic research and high-tech innovation, provide the support and guarantee for the construction of an innovative country.

\section{TRAINING LAW OF TALENTS IN INNOVATION AND ENTREPRENEURSHIP}

\section{A. Three Creative Concepts and Innovative Entrepreneurship Education}

Creation is the act of linking two or more concepts or things in a certain way in order to achieve a certain purpose. In short, creation literally means producing or creating something that never existed before. This is clearly a typical human autonomy. Therefore, one of the greatest characteristics of creation is the conscious exploration of the world.

Innovation is a conceptualization process characterized by new thinking, new inventions and new descriptions. Derived from Latin, it has three meanings; first, renewal; second, creation of something new; third, change. Innovation is man's unique cognitive ability and practical ability. It is an advanced form of human subjective initiative and an inexhaustible motive force to promote national progress and social development. If a nation wants to walk in the forefront of the times, it can not do without theoretical thinking for a moment and can not stop theoretical innovation for a moment. Innovation plays an important part in the study of economics, business, technology, sociology, and architecture.

Entrepreneurship refers to a person found some information, resources, opportunities or master something, or by borrowing the corresponding platform or carrier, the discovery of information and technology resources, opportunity or master, in a certain way, transformation, create more wealth, value, process and realize a pursuit or goal.

Innovation, creativity and entrepreneurship, these three words are just one word, its meaning is different. Innovation means to carry out certain reforms and updates on the basis of the existing material, and promote the functions and values of the original things. Creation refers to the existence of a material or spiritual ideology that originally did not exist under the guidance of the theoretical basis and through experiments, exploration, and other methods. While the scope of entrepreneurship is higher than the previous two levels, refers to the creation or creation of new things into the largest social value of a process. The whole process is often very complex and difficult. Not only including the material, technology, way of innovation, new materials development and so on, more is to include a new business model, new business, new ideas, management consciousness etc...

As for the connotation of innovation and entrepreneurship education, there is no uniform standard in academia, but the essence of it is the same.

Educational innovation is different from a new mode of education education, conservative education or traditional education, the core idea is to cultivate students' innovative spirit and ability of innovation quality.

The core values of entrepreneurship education and entrepreneurship education is the cultivation of dedication and pioneering skills. It is a pioneering education, which is the basic meaning of entrepreneurship education.

In combination with the above two points, it is easy to see that both creative education and entrepreneurship education have a common point of "creating new ideas and things". We regard innovation and entrepreneurship education as the pioneering education of innovative talents. Innovation and entrepreneurship education is based on innovative education.

\section{B. Characteristics of Innovation and Entrepreneurship Education}

Innovation and entrepreneurship education has the frontier. The concept of innovation and entrepreneurship education has not been developed for 20 years so far. The formal proposal and development in China have only about 10 years. Therefore, there is no complete educational model for reference, which requires continuous exploration in practice and continuous progress in exploration. Because of its forward nature, the implementation of innovation and entrepreneurship education has put forward higher requirements for the social environment.

Innovation and entrepreneurship education is practical. Compared to other innovative entrepreneurship education mode of education, should be pay more attention to students' practice, therefore, in the process of the cultivation of students, for students to build more suitable for the development of innovation and entrepreneurship platform, vigorously promote entrepreneurship practice teaching. Students allow mistakes in the process of practice, allow failure, and constantly sum up experience after failure, and grasp the skills of innovation and entrepreneurship.

Innovation and entrepreneurship education is flexible. There is no fixed model for innovation and entrepreneurship education, and the educational model and the choice of educational materials are very flexible. At the same time, a new idea of innovation and entrepreneurship in the generation and application of the environment and the different time, the value generated will be different, therefore, in the process of education according to local conditions, time, special background should have its special education mode. 


\section{CONSTRUCTION OF PERSONNEL TRAINING MODEL BASED ON THREE CREATIVE EDUCATION}

\section{A. Construction of Three Creative Education Mode for College Students Adapting to Local Universities}

The students' extracurricular activities, academic competitions, education, humanities and ideological quality brand lectures, community activities, theory and humanities contests, arts and sports activities, social activities, the two classroom activities and integrated classification of occupation skill training into the personnel training program. The training program includes training plan, improve research and innovation and entrepreneurship training program, science and technology competition plan and humanistic quality plan and occupation skill training plan five aspects (five sub plan) each sub plan contains several projects, each project is composed of several specific project activities (shown in Fig. 1). Forming a unique four creative education and practical training model. In the professional training program, a series of innovative courses (including required courses and optional courses) are set up, and a series of lectures on innovative courses are set up in the second class activities.

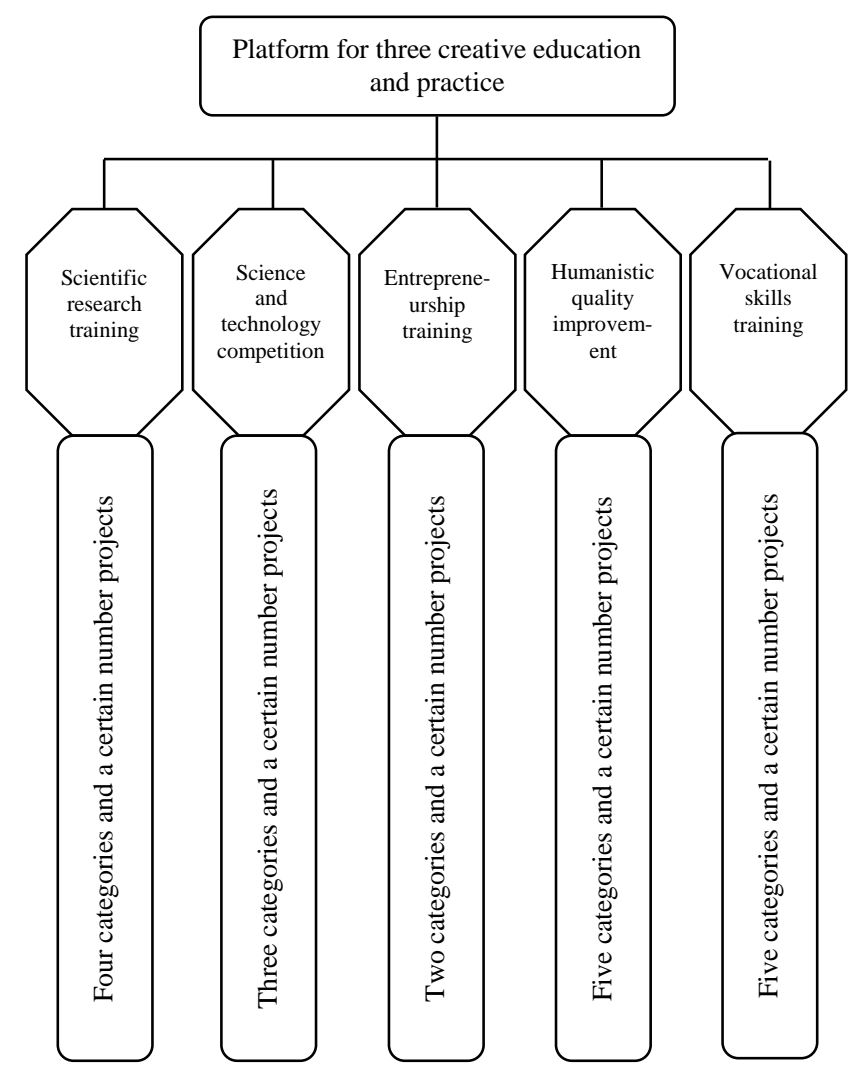

Fig. 1. The talent training mode of innovation and entrepreneurship

Scientific research and innovation training program is mainly organized to carry out various kinds of scientific research (including student application, research projects, participation in teacher research, etc.), technical inventions, innovative experiments, open experiments and other activities. Entrepreneurship training program is mainly organized to carry out entrepreneurship education and entrepreneurial practices. The science and technology competition plan is mainly organized to participate in subject competition, Challenge Cup competition and other professional skills competition. The plan for improving the quality of humanity is mainly organized to carry out mass organizations activities, theories and humanities competitions, mass (non professional) literary and artistic sports activities and social practice activities. The vocational skills training program is designed to encourage students to participate in foreign language skills, computer applications and professional qualifications, professional skills training and certification activities.

According to the training target of "Four Innovation Education", the knowledge structure, skill system and quality requirements of talents training should be systematically and concretely solved, and the scientific and effective talents training program should be formulated and implemented. The talent training scheme in addition to training students to master the basic professional knowledge and professional skills, but also need to cultivate the students' humanities, law, management and other aspects of knowledge, cultivating students' awareness of innovation and entrepreneurship and entrepreneurial ability etc..

\section{B. Reforming and Strengthening the Curriculum System of Three Creative Education}

Bring three creative education into the teaching plan and credit system of professional education and cultural quality education, and establish a multi-level and three-dimensional three creative education curriculum system. At the same time, the reform of teaching methods should be carried out, and the student oriented teaching view should be clearly defined. The guidance of professional teachers, employment guidance teachers to carry out the three hit theory and practice of education, actively from all sectors of society to hire entrepreneurs, entrepreneurs, experts and scholars as part-time teachers, the establishment of a special combination of highquality teachers.

Regularly invited well-known experts and scholars around the campus, the research status of the domestic and international open high level lectures for students; invite outstanding achievements past contestants introduce valuable experience for students participating; according to the previous contest theme and review rules written entry guide, start from the details to illustrate the various matters needing attention. At the same time, in the long run, we will gradually establish and improve competition training guides, contact databases and competition data databases, and accumulate resources.

\section{Improve the Rules and Regulations, Security System and Incentive Mechanism to Build a Three Platform for Education and Practice}

In order to make the students hit three education can be standardized, orderly, long-term development, motivating students to actively participate, and ultimately build a three purpose and effect of education and practice platform, need to establish a set of guiding significance, suitable for students of all levels of laws and regulations guarantee system and 
incentive mechanism, and ensure the implementation uniform, put in place.

Three, the platform of education and practice as the most powerful support for students' extracurricular scientific and technological innovation practice is the key to determine whether the platform can really play its role. Therefore, on the one hand to ensure the construction funds, on the other hand should be closely combined with professional features to strengthen organizational leadership and technical guidance, will also need some professional characteristics of major science and technology competition into the form of fixed project, the extracurricular technological innovation activities in the steady construction and development process has always been full of vitality. By organizing entrepreneurship, innovation competition, lectures, forums, etc. in the practice of simulation platform, in both inside and outside the science and technology competition organized by the organization and students, enrich students' experience and knowledge innovation, enhance students' spirit of innovation and entrepreneurship. With the well-known domestic and foreign enterprises to carry out research cooperation, the enterprise fund jointly held the student science and technology competition, set up a joint laboratory for students of science and technology training, the establishment of training base to provide a platform for the students' social practice.

\section{CONCLUSIONS}

Construction of training mode of three creativity education innovation and Entrepreneurship Based on attention to the class of innovation and entrepreneurship education, strengthen the construction of campus innovation base, expand extracurricular academic activities and improve the innovation ability of science and technology, competition prize grade, promote the practice of the construction of entrepreneurship training center; basic knowledge of male professional thick, wide adaptability, service for local economy, with the spirit of hard work and innovation consciousness of innovation and entrepreneurship.

Through the system of teaching theory and practice integration, effective combination of internal and external practice platform, innovation and entrepreneurship education to carry out the whole program, three-dimensional, systematic, personalized, cultivating high-quality innovative active spirit of innovation and strong independent entrepreneurship entrepreneurial talent.

- All students will develop their spirit of innovation and entrepreneurship through the innovation and entrepreneurship education of general knowledge and autonomy, strengthen the motivation of students' study and practice, and improve their employment competitiveness;

- For technical innovation and entrepreneurial orientation of the students (mainly for students majoring in science and technology), in general the basic innovation and entrepreneurship education, cultivate the technological innovation and achievement transformation ability, and students the basic knowledge and skills;

- For the management of entrepreneurial orientation (management students) and the cultural art market type (with entrepreneurial tendencies of literary and artistic students) students in general on the basis of innovation and entrepreneurship education, cultivate the market marketing, enterprise operation management knowledge and ability, and students the basic knowledge and skills;

- There is a strong entrepreneurial motivation, and have a certain entrepreneurial ability of students in improving their entrepreneurial knowledge and ability at the same time, through training, combat, and funding, site support, guidance and support them to go on the road of entrepreneurship independently.

\section{ACKNOWLEDGMENT}

This work was supported by the Education Teaching Reform Project in Guangxi University of Science and Technology (Grant No. 2016-01)

\section{REFERENCES}

[1] Helge Berglann, Espen R. Moen, Knut Roed, "Entrepreneurship: Origins and returns," Labour Economics, vol. 18, pp. 180-193, 2011

[2] Bingbing Yan, Tianlu Wei, Dejun Li, "Analysis and countermeasures on the current situation of college enrollment education mode in local colleges and universities," Education and Vocation, No. 7, pp. 25-27, 2016.

[3] Jerome A. Katz, "The chronology and intellectual trajectory of American entrepreneurship education 1876-1999,"Journal of Business Venturing, vol. 18, pp. 283-300, 2003.

[4] Yu Zhaoqin, Wu Fugen, Guo Zhongning, "Project-driven based modern engineering training methods," Research and Exploration in Laboratory, vol. 31, pp. 131-133, 2012.

[5] Semra Guven, "World Conference on Educational Sciences 2009 New primary education course programmes and entrepreneurship," Procedia Social and Behavioral Sciences, pp. 265-270, 2009.

[6] Peterman N E, Kennedy J, "Enterprise education: influencing students' perceptions of entrepreneurship," Entrepreneurship Theory \& Practice, vol. 28, pp. 129-144, 2003.

[7] Sha shujing, "Based on project driven mechanical professional teaching model to explore and practice," Journal of Changchun University of Science and Technology, No. 7, pp. 207-208, 2012.

[8] Liu Fengfu, "Implementation of innovative education to cultivate the innovative talents," Technological Pioneers, No. 2, pp. 214-215, 2012.

[9] Wang Haocheng, Feng Zhiyou, Wang Wentao, "Construction of laboratory of thinking innovation based on cultivating innovative spirit and practical ability," Experimental Technology and Management, vol. 30, pp. 198-200, 2013.

[10] Li Zehui, "Application of project-driven mode in the engineering knowledge course," Experiment Science and Technology, No. 9, pp. 133-134, 2011. 